\title{
NOTE
}

\section{THE UNIFORM COMMERCIAL CODE AND AN INSOLVENT SELLER'S POSSESSION OF GOODS SOLD}

The adoption of the Uniform Commercial Code ${ }^{1}$ in its present form may substantially affect the rights of various parties who may have interests in goods that are in the possession of a seller who becomes insolvent. In particular, when the goods involved had been previously sold to a buyer, with the seller nevertheless retaining possession, the buyer's efforts to obtain possession of the goods he had bought may be resisted by creditors who want to get satisfaction for their debts from all of the seller's assets, including these goods. This Note will examine how existing law compromises the conflicting interests of the buyer and the creditors and the effect that the Code will have on the problem.

\section{The Conflicting Interests}

\section{Creditors}

Both the buyer and the creditors can present strong arguments to support awarding a judgment in their interest. One of the best known rationales behind recovery by the creditors is the doctrine of "ostensible ownership." It was thought that the buyer and the seller, by agreeing to allow the seller to continue in possession of the goods, had created the appearance that the seller owned the goods-a circumstance likely to prejudice any creditor who might rely upon this apparent ownership. "Possession with the appearance of ownership renders the property liable for the debts of the possessor to those who gave him credit on the faith of it." 2

This supposition that creditors rely upon possession of specific goods is of doubtful validity today. While reliance on specific assets may be significant in neighborhood or non-commercial dealings, in the large bulk of modern commercial transactions, such reliance is unusual either in making the initial decision to extend credit or influencing an existing creditor of his most advantageous course of conduct.

1. The Uniform Commercial Code was proposed by the American Law Institute and has been adopted in Pennsylvania. PA. Stat. ANN. tit. 12A (Purdon 1954).

2. Ryall v. Rowles, 1 Ves. Sr. 348 (1749). For a discussion of the doctrine of reputed or ostensible ownership, see 1 Glen, Fraudulent Conveyances and PREFERENCEs $\$ \$ 341-343 c$ (rev. ed. 1940). 
Extension of Credit.-In normal commercial transactions, the creditor makes his decision on whether or not initially to extend credit primarily in reliance upon the seller's business prospects and credit history. ${ }^{3} \mathrm{He}$ is likely to place principal emphasis upon indications of the seller's anticipated income, since that is the source out of which the debt will be satisfied in the normal course of events. ${ }^{4}$ The prudent creditor cannot overlook the possibility that the anticipated receipts may not materialize, however, and so must also take note of the seller's ability to weather normal business hazards as reflected by the seller's net asset position. In neither event is it probable that he secures this information by inspecting what specific goods are in seller's possession. Rather, this data is derived from financial statements procured from credit agencies or directly from the seller and from interchanges of ledger information among the seller's suppliers which indicate the current position of the seller's trade liabilities and how he is meeting them. ${ }^{5}$

Pre-existing Debt.-Reliance by creditors who had extended credit before the purchase of the goods in question is also unlikely. Although the seller's retention of the goods sold would reveal no change in the seller's financial position, the decision to extend further credit or to press existing claims more likely is made on the basis of other indications of financial stability such as the filing of security interests on the seller's assets, the institution of suit against the seller by other creditors, ${ }^{6}$ or revised credit ratings. ${ }^{7}$

Attaching Creditor.-The one person who undoubtedly has relied on the seller's possession is the creditor who levies on the goods. If, subsequently, he should lose the goods to the buyer, the seller's assets may then be insufficient to satisfy the creditor's claim. Some assets may have disappeared while others may have been attached by other creditors. Although liens obtained by other creditors on the seller's assets can be voided in

3. Jacoby \& Saulneir, Term Lending to Business 80-81 (1942); Schultz \& Reinhart, Credit and Collection Management 245-54 (2d ed. 1954).

4. JACOBY \& SAUlNiER, op. cit. supra note 3 , at 81 .

5. Schultz \& Reinhart, op. cit. supra note 3, at 248-50. Commercial banks, for example, are unwilling to extend term credit to a concern with a ratio of current assets to current liabilities which is less favorable than $2 / 1$. Credit is commonly refused to firms engaged in accounts receivable financing since this indicates a lack of working capital. On the other hand, concerns which have mortgaged their fixed assets are often granted term loans provided there is an adequate cushion of equity and an established earning power. JACOBY \& SAULNIER, op. cit. supra note 3 , at 82.

6. In some metropolitan areas a commercial market has been found for daily litigation lists. The institution of suit against a customer may at least cause an investigation of his credit standing. SCHULTZ \& REINHART, op. cit. supra note 3, at 96-98. Exchanges in ledger information give a more precise indication of changes in credit standing. Many credit agencies provide their subscribers with lists of delinquent debtors.

7. Many sources indicate changes in credit standing. The Dun \& Bradstreet Reference Book is issued six times a year. Credit Exchange issues a Weekly Change List containing the latest information on accounts on which there has been a change in recommendation. Id. at 59,88 . 
bankruptcy, ${ }^{8}$ proceedings may be to no avail, ${ }^{9}$ legally impossible ${ }^{10}$ or so expensive as to be prohibitive.11

The "ostensible ownership" theory stresses the fact that a creditor may act in reliance on the seller's possession of specific goods. An equally important consideration arises quite apart from reliance. Conveyances for little or no consideration to a cooperative "buyer" have been used frequently in an effort to place the "seller's" assets beyond the reach of creditors. Retention under these circumstances does not in itself harm the creditors, but it makes the "conveyance" so advantageous that it has long been considered a badge of fraud. ${ }^{12}$

\section{Buyers}

Balanced in opposition to the interests of the creditors of the insolvent seller is the desire of the buyer to obtain possession of the goods he contracted to purchase. There are many situations in which it is commercially reasonable, or even necessary, that the seller continue to hold the goods after the sale. For example, the buyer may not have storage space available to accept delivery, the seller may be unable to make immediate shipment, or the buyer may intend to resell so that shipment to him would be economically wasteful. In other cases it may have been necessary for the buyer to make an advance payment to enable the seller to obtain the basic goods which the seller is holding to process or complete. Thus legitimate business purposes, and not only an intent to defraud creditors, may underlie the fact that seller had possession of buyer's goods at the time of insolvency.

The situation in which the conflict of interest is most difficult to reconcile arises when the buyer has made a partial or total advance payment to the seller. When insolvency occurs, the prepayment may have been used by the seller in an effort to alleviate his financial pressures. Obviously, in such a case, both the buyer who advanced the money and the creditors who seek satisfaction from the goods cannot be made whole. If the buyer prevails, he will pay in only the balance of the price due, leaving the creditors with fewer assets out of which to settle their claims. If the creditors prevail, the buyer is forced to recoup his losses along with the

8. Section $67 \mathrm{a}(1)$ of the Bankruptcy Act provides that every lien obtained by legal or equitable process within four months of the filing of the petition in bankruptcy shall be null and void if the debtor was insolvent at the time the lien was obtained. 66 STAT. 427, 11 U.S.C. \$107a(1) (1952).

9. If four months have passed between the attachment and the filing of the petition in bankruptcy, the lien is not voidable. Ibid.

10. Involuntary proceedings in bankruptcy can be instituted only by three or more creditors who have provable, liquidated claims. 66 STAT. 425,11 U.S.C. $\$ 95 \mathrm{~b}$ (1952). It must be shown that an act of bankruptcy has been committed as defined in section 32 of the Bankruptcy Act, 66 STAT. 421, 11 U.S.C. \$21(a) (1952).

11. In recent years the costs of bankruptcy have absorbed about one quarter of all the available bankruptcy assets. Schultz \& ReINHART, op. cit. supra note 3 , at 430 .

12. See Twynes Case, 3 Co. Rep. 806 (1601). 
general creditors, instead of coming out substantially unscathed from the transaction.

Even if the buyer has not prepaid on the purchase contract, the reconciliation of competing claims of the buyer and the creditors is not easy. It would appear that in such a circumstance, the reasonable solution is to allow the buyer to take possession upon payment of the price into the fund available to creditors. The buyer is thus protected from the ramifications that could result from failure to receive the goods as anticipated under his contract with seller if the goods were not replaceable. Even if he can secure the goods elsewhere, the buyer may be under contract to resell and it may be too late to avoid being in default to his obligee. Certainly the creditors seem to have no reason to complain, especially if the goods are manufactured to the buyer's specifications and hence not marketable to others. However, such a solution is premised upon the contract price equalling the fair market value of the goods at the time of insolvency. If there has been an appreciable rise in the value of the goods, creditors will be most unwilling to allow buyer to take the goods upon paying in an amount less than their actual worth.

\section{PrIOR LAW ${ }^{13}$}

State courts and legislatures have evidenced disapproval of the seller's retention of the goods sold when claims of creditors intervene. ${ }^{14}$ Unless delivery is made within a reasonable time, some jurisdictions have allowed the levying creditor ${ }^{\mathbf{1 5}}$ to void the transaction as a matter of law regardless of the good faith of the parties. ${ }^{16}$ A larger number of states have adopted the rule that a retention transaction is only presumptively fraudulent, ${ }^{17}$

13. The term "prior law" is used in this Note to identify the law applicable in a jurisdiction before the Uniform Commercial Code is adopted. Depending on the jurisdiction, this may mean common law, the Uniform Sales Act, when applicable, or supplementary legisiation.

14. Most states have passed statutes specifically aimed at the creditor's rights in retained goods. Only New Mexico has failed to pass on this matter either by statute or decision. All the other states have established obstacles to the buyer's recovery as against the seller's creditors. 2 WILLISTON, SALES $\$ \$ 349-404$ (rev. ed. 1948).

15. Some cases have held that the doctrine is limited to levying creditors, e.g., Clough v. Glines \& Stevens Co., 77 N.H. 408, 92 Atl. 803 (1914); McGann v. Capital Saving Bank \& Trust Co., 117 Vt. 179, 89 A.2d 123 (1952); cf. Daniels v. Nelson, $41 \mathrm{Vt} .161$ (1868) (rule does not apply against tax collectors); see also Murphy v. W. T. Murphy \& Co., 126 Iowa 57, 101 N.W. 486 (1904). Many of the statutes, however, state that both prior and subsequent creditors may take advantage of the rule. E.g., Ind. Ann. Stat. \$33-107 (Burns 1949); Minn. Stat. ANN. \$513.12 (West 1947); OkLa. Stat. ANN. tit. 24, \$6 (1937).

At least one court has taken the view that the doctrine is limited to subsequent creditors. Smith v. Cooper Marble Co., 48 Ohio App. 65, 192 N.E. 282 (1933). Others appear to limit it to pre-existing creditors. McCullough v. Wiley, $192 \mathrm{~Pa}$. 176, 43 Atl. 999 (1899); see WASH. REv. CODE $\$ 65.08 .040$ (1951).

16. E.g., Caz. Crv. Code $\$ 3440$ (1949); OkLa. Stat. ANn. tit. 24, §6 (1937); Southern California Collection Co. v. Napkie, 106 Cal. App. 2d 565, 235 P.2d 434 (1951); Callahan v. Union Trust Co., 315 Pa. 274, 172 Ati. 684 (1934).

17. E.g., Wooley v. Crescent Automobile Co., 83 N.J.L. 244, 83 At1. 876 (Sup. Ct. 1912) ; Holley v. A. W. Haile Motor Co., 188 App. Div. 798, 177 N.Y. Supp. 429 (4th Dep't 1919); ArIz. Code ANN. \$58-103 (1939); KaN. GEN. Stat. \$33-103 (1949). 
while a few states have supplemented one or the other of these rules with the requirement that the bill of sale be recorded if the buyer is to prevail. ${ }^{18}$

In a presumption jurisdiction, the interests of a legitimate buyer are not seriously jeopardized. Evidence that adequate consideration was given ${ }^{19}$ and that there was no intent to defraud the seller's creditors ${ }^{20}$ will overcome the presumption. Evidence of the buyer's good faith will generally suffice, ${ }^{21}$ but, in at least one jurisdiction, the seller's good faith must be proved as well. ${ }^{22}$ In addition, a reasonable explanation for the failure to take immediate delivery may be required..$^{23}$

The buyer in a fraud-in-law jurisdiction will lose his interest in the goods unless the seller's retention is reasonable in point of time. What constitutes a reasonable time depends to some extent on the buyer's diligence in preparing to remove the goods ${ }^{24}$ and his ability to take immediate delivery of the type of goods in question. ${ }^{25}$ In general, however, a reasonable time seems to be construed as the shortest time in which it is physically possible for the buyer to accept delivery. ${ }^{28}$ If the goods are bulky, the buyer may effect a constructive delivery by identifying the goods as his own, ${ }^{27}$ but his failure to do so may defeat his claim even though actual immediate delivery may be commercially infeasible. ${ }^{28}$ In some states, actual

18. Per se rule applicable if bill of sale is not recorded: Hawant REv. LAwS c. 308: \$12758 (1945); IowA Code ANN. \$556.3 (1951); MD. ANN. Code Gen. LAws art. 21, $\$ 49-59$ (1951) ; WAsH. REv. CODE $\$ 65.08 .040$ (1953). Presumption rule applicable if bill of sale is not recorded: D.C. CoDE ANs. $\$ 42-101$ (1951); N.D. REv. CoDE $\$ 12-0106$ (1943) ; Splain v. B. F. Goodrich Rubber Co., 290 Fed. $275,277-78$ (D.C. Cir. 1923). In some cases, even if the bill of sale is recorded, the buyer may have to rebut a presumption of fraud. KY. REv. STAT. $\$ 378.040$ (1953); VA. CODE $\$ \$ 55-96$ (1950).

19. Scruggs v. Blackshear Mfg. Co., 45 Ga. App. 855, 166 S.E. 249 (1932).

20. Burke v. Sharpe, 88 Ark. 433, 115 S.W. 145 (1908); Holley v. A. W. Haile Motor Co., 188 App. Div. 798, 177 N.Y. Supp. 429 (4th Dep't 1919).

21. Tousley v. First Nat'l Bank, 155 Minn. 162, 193 N.W. 38 (1923) ; Houlley v. A. W. Haile Motor Co., 188 App. Div. 798, 177 N.Y Supp. 429 (4th Dep't 1919) (by implication).

22. Kruse v. Carey, 259 Mich. 157, 160, 242 N.W. 873, 874 (1932).

23. E.g., Ward v. Shirley, 131 Ala. 568, 23 So. 489 (1902); Freedman v. Avery, 89 Conn. 439, 94 Atl. 969 (1915); see Volusia County Bank v. Bertola, 44 Fla. 734, 738, 33 So. 448, 450 (1902).

24. Compare White v. Pease, 15 Utah 170, 49 Pac. 416, 417 (1897), with Seymour v. O'Keefe, 44 Conn. 128, 131 (1876).

25. Taylor v. Smith, 17 B. Mon. 536 (Ky. 1856) ; State ex rel. Baumunk v. Goetz, 131 Mo. 675, 33 S.W. 161 (1895); see Meade v. Smith, 16 Conn. 346, 364 (1844) (dictum); Trimble v. Hunt, 169 Ill. App. 259, 262 (1912) (dictum); cf. Freedman v. Avery, 89 Conn. 439, 94 Atl. 969 (1915); McCullough v. Willey, 200 Pa. 168, 49 Atl. 944 (1901).

26. State ex rel. Baumunk v. Goetz, 131 Mo. 675, 680, 33 S.W. 161, 162 (1895); Bishop v. O’Connell, 56 Mo. 158 (1874).

27. Crymble v. Mulvaney, 21 Colo. 203, 40 Pac. 499 (1895); Dover Lumber Co. v. Whitcomb, 54 Mont. 141, 168 Pac. 947 (1917); Western Mining Supply Co. v. Quinn, 40 Mont. 156, 105 Pac. 732 (1909).

28. Seymour v. O'Keefe, 44 Conn. 128 (1876); Jacobson v. O'Keefe, 190 III. App. 266 (1914). But see Carroll v. Haskins, 212 Mass. 593, 99 N.E. 477 (1912); see also Thompson-Starrett Co. v. Plunkett, 89 Vt. 177, 94 At1. 845 (1915). 
delivery is required despite an agreement that the seller is to act as the buyer's agent ${ }^{29}$ or bailee. ${ }^{30}$

The Uniform Sales Act did nothing to change the law of seller retention. Section 26 of the act provides:

"Where a person having sold goods continues in possession of the goods . . . and such retention of possession is fraudulent in fact or is deemed fraudulent under any rule of law, a creditor or creditors of the seller may treat the sale as void."

However, the adoption of the Uniform Fraudulent Conveyances Act might be construed as an implied repeal of the fraud-in-law doctrine. ${ }^{31}$ Section 7 provides:

"Every conveyance made and every obligation incurred with actual intent, as distinguished from intent presumed in law, to hinder, delay, or defraud either present or future creditors, is fraudulent as to both present and future creditors."

While the act does provide for voiding conveyances under special circumstances without regard to intent, 32 it has no provision regarding seller retention. Despite the act's apparent comprehensiveness, the fraud-in-law rule has been applied without mention of the effect of the adoption of the statute. ${ }^{33}$

In any case, none of the applicable rules regarding seller retention satisfactorily balance the interests of buyers and creditors. Although the application of the presumption that the transaction is fraudulent protects the creditor against fraudulent conveyances, it gives little protection against the seller's misrepresentations since only proof of the buyer's good faith is generally required. ${ }^{34}$ Moreover, the buyer's good faith is of little satis-

29. Seavey v. Walker, 108 Ind. 78, 9 N.E. 347 (1886); Clark v. Porter, 180 Okla. 179, 68 P.2d 844 (1937). However, once buyer has taken possession, he may redeliver it to seller. White v. O'Brien, 61 Conn. 34, 13 At1. 750 (1891) ; Deere v. Needles, 65 Iowa 101, 21 N.W. 203 (1884). There seems to be a. distinction drawn between sales in bulk and single items. Compare Clark v. Porter, supra, with Keller v. Tracy, 183 Okla. 463, 82 P.2d 1046 (1938), and Kaplinski v. Horwitz, 114 Conn. 523, 159 At1. 351 (1932).

30. O'Connor v. O'Connor, Rice \& Barnes, Inc., 44 Cal. App. 2d 1, 111 P.2d 656 (1941). But cf. Kaplinski v. Horwitz, 114 Conn. 523, 159 At1. 351 (1932); Thompson v. Esty, 69 N.H. 55, 45 Atl. 566 (1896).

31. The Commissioners' prefatory note states that the uniform law was required by the confusions and uncertainties of the existing law, one of which was ". . the attempt to make the Statute of Elizabeth cover all conveyances which wrong creditors, even though the actual intent to defraud does not exist." 9A UNIFORM LAWS ANN. 43 (1951).

32. Fraudulent intent is not required to invalidate conveyances by a person who is or will be thereby rendered insolvent (\$4); conveyances made without fair consideration which leave unreasonably small capital in the hands of the transferor $(\S 5)$; conveyances made without fair consideration by one who "intends or believes that he will incur debts beyond his ability to pay as they mature." ( $\$ 6$ ). (1928).

33. See Shipler v. New Castle Paper Products Corp., $293 \mathrm{~Pa}$. 412, 143 Atl. 182

34. See text at note 22 and note 22 supra. 
faction to the levying creditor who may be unable to satisfy his claim if he loses the goods to the buyer. The fraud-in-law rule protects the creditors from the risk of loss, but its strict construction of reasonable time fails to take into account the commercial needs of buyers in allowing the seller to retain the goods. When advance payments are made, the buyer's only resort is that of a general creditor of the seller, and his failure to receive the goods may force him to breach his obligations to other parties.

\section{Seller Retention Under the Sales Article}

\section{The Basic Provision}

Although the Uniform Commercial Code continues, at least to some extent, the approach of the Uniform Sales Act in following the local law, it also evidences an awareness of the legitimate business purposes to be served by seller retention. Section 2-402(1) provides:

"A creditor of the seller may treat a sale or an identification of goods to a contract for sale as void if as against him a retention of possession by the seller is fraudulent under any rule of law of the state where the goods are situated, except that retention of possession in good faith and current course of trade by a merchant-seller for a commercially reasonable time after a sale or identification is not fraudulent."

The use of the phrasing "fraudulent under any rule of law" indicates that the exception to the creditor's right to void the transaction is intended to affect only the law of the fraud-in-law jurisdiction. This conclusion can be supported by either of two theories. First, it may be argued that the words "rule of law" do not include a presumption. While some rules of law masquerade as "presumptions," 35 they are conclusive and irrebutable and thus do not encompass the type of presumption found in a presumption jurisdiction. If it is accepted that the presumption doctrine is not incorporated into this section of the Code, the exception clause would be inoperative in the presumption jurisdiction because the exception modifies only an existing rule of law which has been incorporated into the Code. Under the second theory, even if the law of a presumption jurisdiction is codified by the Code's acceptance of existing law, the exception clause would not cause a different effect in transactions to which it is applicable. No sale would be deemed "not fraudulent" under the exception if the presumption doctrine would have reached an opposite result. ${ }^{36}$ The fact

35. See, e.g., 9 WIGMORE, Evidence $\$ 2492$ (3d ed. 1940).

36. Superficially it appears that a different result may be reached because the exception clause requires good faith on the part of the seller while the presumption rule turns on the good faith of the buyer. Even if this distinction exists, it is virtually impossible to imagine transactions in which the buyer could be acting in bad faith if the seller is deemed to have acted in good faith.

The theory that section $2-402$ applies to a presumption jurisdiction but makes no change is consistent with the recent statement by the draftsmen that ". . . the 
that the exception clause is not so broad as the presumption of prior law is explained by the comment of the draftsmen that the section was drafted with the limited purpose of serving the legitimate business interests of buyers and sellers in the retention transaction without unnecessarily affecting local law on questions of hindrance of creditors. ${ }^{\mathbf{3 7}}$ Thus in a presumption jurisdiction, the buyer's burden of proof remains unchanged, but in a fraud-in-law state, the buyer may defeat the creditor's claim by showing that the goods were retained in good faith and current course of trade by a merchant-seller for a commercially reasonable time.

Merchant-Seller.-One of the major limitations on the applicability of the Code's exception is the requirement that retention must be by a merchant-seller. A merchant is defined as "a person who deals in goods of the kind or otherwise . . . holds himself out as having knowledge or skill peculiar to the practices or goods involved in the transaction...."38 Since the definition is phrased in the alternative, a person may be a merchant for one purpose but not for another. For purposes of determining the applicability of the Statute of Frauds ${ }^{30}$ or other sections involving contractual formalities, ${ }^{40}$ any merchant acting in that capacity may be deemed to be aware of normal business practices. However, if the issue were a breach of warranty of merchantable quality, a seller would be a merchant only as to those goods in which he normally deals since it is only in this capacity that the seller would know the standards of quality which would "pass without objection in the trade under the contract description." 41

The latest proposed comment on the definition of a merchant states that for purposes of section 2-402, a person is a merchant only with respect to those goods with which he normally deals. ${ }^{42}$ Since sales of other goods would constitute only a small proportion of commercial transactions, the need for revision of prior law as to these goods is not significant.

Current Course of Trade. - The import of the requirement that retention be in current course of trade is unclear since the term is never defined in the Code. Comment 2 to section 2-402 describes the ambiguous phrase with the equally ambiguous "general commercial understanding of what a 'current' transaction is." 43 The use of similar terms in other articles of the Code would suggest that this may refer to the commercial need for the type of retention involved. A holder of a negotiable document of title,

exception is merely a particular example of the rule that the presumption of fraud is rebuttable by evidence of good faith." UNIForm COMIMERcIAI CoDE, Supplement No. 1, at 102 (Sub-Committee Report 1955).

37. UNIFORM COMMERCIAL CODE \$2-402, comment 1 (hereinafter cited as UCC).

38. UCC \$2-104(1).

39. UCC $\$ 2-201$. Subsection (2) is applicable only to merchants.

40. Several provisions dealing with contract formation are applicable only to merchants. E.g., UCC $\S 2-205$ (firm offers); id. $\$ 2-207(2)$ (additional terms on acceptances).

41. UCC $\$ 2-314$.

42. UCC, Supplement No. 1, at 97 (Sub-Committee Report 1955).

43. UCC \$2-402, comment 2. 
for example, acquires title to the document only if it was negotiated in the "current course of business or financing." 44 The draftsmen explain that the use of this term was intended to protect "that great run of commercial transactions which are patently current and normal" even though this may allow some persons to convey rights which they do not have. ${ }^{45}$ Similarly, a buyer "in ordinary course" is defined so as to exclude pawnbrokers, ${ }^{46}$ and, like negotiations in current course, ${ }^{47}$ does not include transfers for pre-existing debts. ${ }^{48}$

This line of interpretation would indicate that retentions in connection with transfers for past consideration are not in current course. Section $2-402(2)$, the only other section in which the term is used, gives considerable support to this conclusion. It provides:

"Nothing in this Article shall be deemed to impair the rights of creditors of the seller where identification to the contract and delivery are made not in current course of trade but in satisfaction of or as security for a pre-existing claim for money, security or the like and are made under circumstances which apart from this Article would constitute the transaction a fraudulent transfer or voidable preference." ${ }^{49}$

It should be noted that this has no direct application to the problem raised by the seller's retention since it is operative only when both identification and delivery have taken place. However, the appositive use of the term would seem to exclude transfers made for past consideration from the class of current course transactions. On the other hand, this would not exclude enabling advance transactions from current course since the transfer of goods to the advancing buyer is not made in satisfaction of or as security for a pre-existing claim for money. ${ }^{50}$

When new value is given, however, the determination of whether retention is in current course of trade will be extremely difficult. A court is hardly in the position to measure the commercial need of the retention in question so that whether the retention is in fact a common occurrence in commercial transactions will undoubtedly be a major consideration in the court's judgment. In any case, the court may be reticent to make a broad policy judgment on the basis of the current course requirement.

Commercially Reasonable Time.-The use of the word "commercially" in the additional requirement of a commercially reasonable time seems to

44. UCC \$ 7-501 (4).

45. Id. comment 1 .

46. UCC \& 1-201(9).

47. UCC \$7-501, comment 1.

48. UCC \$1-201(9).

49. UCC \$2-402(2) (Emphasis added.)

50. Support for the position that some advances are considered to be given for new value may be found in analogy to $\$ 9-108(2)$. Although the section deals with after-acquired property, it does provide that under certain conditions an advance by the secured party may be deemed as new value. 
be aimed primarily at liberalizing the concept of a reasonable time under prior law in a fraud-in-law jurisdiction. ${ }^{51}$ The extent to which this will change the law is uncertain, but if it is interpreted with reference to the commercial need for the retention transaction in question, a decision on this basis might yield the same result in many cases as would the application of the current course requirement.

Good Faith.-A literal reading of the language of the section will establish that retention by the seller must have been in good faith. Good faith is defined as "honesty in fact in the conduct or transaction concerned" 52 and in the case of a merchant includes "observance of reasonable commercial standards." 53 Yet neither of these definitions clarifies the meaning of the requirement in the section 2-402 exception. It is possible that the need for good faith was inserted only to prevent the sham transaction. However, it may have some more restrictive function if it is interpreted to apply to the seller's subjective intent. It is also unclear whether the good faith requirement was meant to apply in a situation where the decision to retain was made in good faith on the part of both the buyer and seller, but thereafter the seller abused his having possession of the goods by misrepresenting them as his own to a creditor. An acceptable solution would be to interpret the requirement of good faith as merely precluding the buyer's recovery when he, as a reasonable buyer, could have detected that the seller had fraudulent designs in retaining the goods.

A requirement that the buyer also must act in good faith is not so apparent from the language of the Code, but the provision might be so construed. However, the case would rarely arise in which the seller acted in good faith while the buyer did not, and in any case, a bad faith buyer would probably be unable to recover. ${ }^{54}$

As a partial solution to the problem of the seller's retention, the merchant-seller exception of section $2-402$ provides a better balance of the interests of buyers and creditors than did prior law. The limitation of retention to those in current course by a merchant-seller for a commercially reasonable time serves the commercial needs of buyers, and, to a large extent, protects the creditor from the results of his reliance on the seller's possession. Although the terms of the exception tend to merge and are quite vague, this may be necessary to serve the interests of buyers without repealing the fraud-in-law rule entirely. In face of the enormous variety of contingencies which may make retention commercially beneficial, a clearly defined exception cannot be expected. In the presumption jurisdiction, the law remains unchanged so that in many cases, the attaching creditor has no protection from the results of his reliance even though the retention served no significant commercial purpose.

51. See discussion in text at notes 24-27 supro.

52. UCC \& 1-201 (19).

53. UCC $\$ 2-103(1)(b)$.

54. The court might find against the buyer by applying the maxim that unfair or unjust conduct will preclude equitable relief. See Dent v. Ferguson, 132 U.S. 50 (1889) ; Fonner v. Martens, 186 Cal. 623, 200 Pac. 405 (1921); King v. Antrim Lumber Co., 70 Okla. 52, 172 Pac. 958 (1917). 


\section{Buyer's Remedies Under the Code}

The impact of section 2-402 is to define the method of determining whether the buyer or creditors have a superior claim to certain goods. It retains existing law which makes seller retention of the goods fraudulent; the exception clause simply provides that retention under its stated conditions is not fraudulent. Since the language makes no specific provision for remedy, the operative effect of the section must be examined to determine whether or not it is applicable apart from the sections of the Code which expressly create the buyer's proprietary remedies. If the buyer has no claim to possession, he is relegated to the position of other unsecured creditors whose monetary claims are settled without regard to any one specific asset. Therefore, unless the buyer can successfully assert his right to possession of the goods under some other Code provision, it would appear that the creditors need not resort to their right to treat the sale as fraudulent and void.

\section{Buyer's Right to Goods on Seller's Insolvency: Section 2-502}

There are two sections in the sales article which grant the buyer a possessory remedy: section 2-502 and section 2-716. Section 2-502 is designed to deal with the conflicting interest of buyers and the creditors of an insolvent seller. It provides:

". . . a buyer who has paid a part or all of the price of goods [identified to the contract] . . . may on making and keeping good a tender of any unpaid portion of their price recover them from the seller if the seller becomes insolvent within ten days after receipt of the first instalment on their price."

An initial inquiry should be directed toward the fact that the provision is phrased in terms of recovery from the seller, not the seller's creditors. However, since the seller's insolvency would have given his creditors a superior interest in his assets, the draftsmen may have contemplated that the buyer's right to the goods on compliance with the requirements of the section would also prevail over the seller's creditors. Moreover, since specific performance might have been granted under prior law in such a case on grounds of insolvency in spite of attachment liens held by creditors on the goods, ${ }^{55}$ it is doubtful that this provision would have been limited to rights against the seller without comment. ${ }^{56}$

55. Where buyer advanced money for the purpose of enabling the seller to procure or produce goods, some courts have attempted to protect the buyer by describing the relationship as a trust, a pledge or a mortgage. Hurley v. Atchison, T. \& S.F. Ry., 213 U.S. 126 (1909) ; Parker v. Garrison, 61 I11. 250 (1871); Livesley v. Heise, 45 Ore. 148, 76 Pac. 952 (1904); Livesley v. Johnston, 45 Ore. $30,76 \mathrm{Pac}$. 13, 946 (1904). This may be rationalized on the ground that the buyer intended to hold a position other than that of a general creditor. See Horack, Insolvency and Specific Performance, 31 HARv. L. REv. 702, 717-18 (1918). But cf. Quittner v. Los Angeles Steel Casting Co., 202 F.2d 814 (9th Cir. 1953).

56. Unless the attaching creditor is a bona fide purchaser under applicable state law, Bridgham v. Hinds, 120 Me 444, 115 Atl. 197 (1921); Note, 31 Ore. L. Rev. 162 (1952), his rights to the goods stand no higher than the seller's. North Chicago 
Even if a buyer meets all the conditions of section 2-502, the seller's creditors may attempt to thwart buyer's taking possession of the goods by showing the retention did not meet the requirements of section 2-402; for example, the buyer may not have purchased the goods from a "merchantseller." Thus a buyer may qualify under section $2-502$ but not under the exception to section 2-402 which carves out the area in which retention is not deemed fraudulent. If section 2-502 is interpreted to be unrestricted by the requirements of section $2-402$, the Code presents the anomalous possibility that a buyer may recover goods under section 2-502, although the retention was "fraudulent" under section 2-402. Yet, neither the comments nor the cross-references in the Code recognize the possibility of interrelationship between the two sections. ${ }^{57}$ There is no indication in either section which should control in the event of conflict. However, the buyer's right could easily have been subjected expressiy to the requirements of section 2-402 if such had been intended.

Some indication of the proper interplay of these sections might be gleaned from the principle underlying the remedy of section 2-502. It is possible that the provision is based upon the belief that funds given to the seller within ten days of insolvency may still be in his possession. Since creditors will be dividing the seller's assets, which presumably include these funds, it would be equitable to allow the buyer to take the goods for which he paid. If that be the rationale, then it seems logical to conclude that the draftsmen intended to have section 2-502 apply without regard to section 2-402 inasmuch as there is a special principle of the respective interests of buyers and creditors that is fully vindicated in section 2-502. Nevertheless, it must be noted that the basic factual premise that a seller, having received cash near the point of insolvency, will still have that cash some days later is at least dubious.

A different rationale to section $2-502$ is found in the obvious parallel of that section with section 2-702, which authorizes a seller to reclaim goods he delivered to a buyer on credit if the buyer becomes insolvent within ten days after receipt. Both sections cross-refer to the other; therefore it is quite likely that the two sections are based on the same theory. Section 2-702 is straightforward in adopting the idea of "implied fraud." 58 Briefly stated the doctrine is that a buyer who accepts goods shortly before becoming insolvent will be conclusively presumed to have known of his impending insolvency so that his acceptance of goods on credit, operating as a tacit statement of financial ability to pay, is a misrepresentation of his actual financial position. Carried over to section 2-502, this rationale would be that a seller who accepts an advance payment shortly before becoming insolvent will be conclusively presumed to have known of his

Rolling Mill Co. y. St. Louis Ore \& Steel Co., 152 U.S. 596 (1894); Ellery v. Cumming, 40 Ariz. 512, 14 P.2d 709 (1932); Wilson v. Kruse, 270 I11. 298, 110 N.E. 359 (1915); Day v. Traders' Nat'l Bank, 232 Ky. 662, 24 S.W.2d 576 (1930). 57. Some inference can be drawn, perhaps, from the failure of $\S 2-502$ to refer to creditors. See text at notes 55 and 56 supra.

58. See UCC §2-702, comment 2. 
impending insolvency so that his acceptance of the money, operating as a tacit statement of his financial ability to finish and deliver the goods, is a misrepresentation of his actual financial position.

If the "implied fraud" rationale is the one accepted, it is inconclusive as to whether or not section 2-502 is operative independently of section 2-402. The reasoning used before on the premise of the cash still being in the seller's hands emphasized the consideration of the creditors' interests in creating the remedy. The same is not true of "implied fraud." That considers only the rights of buyer vis-à-vis the seller; it is premised on the seller's defrauding the buyer. In fact, the language of the section refers to recovery "from the seller." If the draftsmen were not advertent to reconciling the interests of buyers and creditors, it cannot be said that they intended section 2-502 to operate without regard to some provision which does deal with buyers versus creditors. If any conclusion is to be drawn, therefore, it would be that there is little in the present Code that aids in deciding whether a buyer is not entitled to the remedy of section 2-502 if his rights can be set aside by creditors under section 2-402.

The foregoing discussion indicates the problems that may arise in fraud-in-law jurisdictions on attempting to reconcile sections 2-402 and 2-502, but even in a presumption jurisdiction, where the exception in section $2-402$ is inapplicable, ${ }^{59}$ the operation of section 2-502 is not perfectly clear. Section $2-502$ has no requirement of good faith while the presumption doctrine turns principally on that issue. ${ }^{60}$ Thus the same anomalous possibility arises, even in a presumption jurisdiction, that the buyer could recover under the Code even though the seller's retention is deemed fraudulent under existing law. The stringent requirements of section 2-502 that the buyer must have prepaid the first installment within ten days before the seller's insolvency would limit the number of situations in which this conflict arises, but the problem merits clarification by draftsmen and revisers.

Bankruptcy Act Restrictions.-The scope of applicability of section 2-502 may be considerably smaller than would appear from its language. Since the buyer's right under section 2-502 is predicated on the seller's insolvency, it might be held that the buyer's recovery constitutes a voidable preference under the Bankruptcy Act. ${ }^{61}$ The federal statute specifies that for purposes of the provision defining preferences,

". . . a transfer of property other than real property shall be deemed to have been made or suffered at the time when it became so far perfected that no subsequent lien upon such property obtainable by legal or equitable proceedings on a simple contract could become superior to the rights of the transferee." 62

59. See text at note 36 supra.

60. See text at notes 21 and 22 supra.

61. 52 Stat. 840 (1938), as amended, 11 U.S.C. $\$ \$ 1-1103$ (1952).

62. 64 SтAт. 25 (1938), 11 U.S.C. $\$ 96 a(2)$ (1952). 
If the buyer's interest in the goods under section 2-502 is not transferred to him until the seller's insolvency, then granting buyer possession will be a voidable preference. ${ }^{63}$ However, if section 2-502 is interpreted as transferring some right to the buyer when he prepays, a right which is later matured if the seller becomes insolvent within ten days, then the transfer may be deemed effected before the seller was insolvent and not rendered voidable by the Bankruptcy Act.

The subcommittee report on section $2-502^{64}$ meets the contention that the provision creates a voidable preference by referring to authority that delivery of goods pursuant to a pre-existing contract of sale is not a preference. ${ }^{65}$ However, it does recognize that such questions are outside the realm of state law. Therefore, if there is a conflict with provisions of federal law, the buyer's remedy under section 2-502 will be ineffectual.

Under prior law, the buyer was in a similar position. When the goods attached were in various stages of completion, the buyer was allowed to recover only those goods which had been appropriated to the contract, 6 and in the fraud-in-law jurisdiction, might lose his rights to even these goods. Unless the buyer's title to the goods was perfected prior to the seller's insolvency, delivery of the goods to the buyer constituted a voidable preference in bankruptcy. ${ }^{67}$

The effect of the interposition of the Bankruptcy Act will be significant only to the extent that the seller's insolvency is defined in the Code as insolvency "within the meaning of the federal bankruptcy law." 88 Since the Code also defines an insolvent person as one "who either has ceased to pay his debts in the ordinary course of business or cannot pay his debts as they become due," ${ }^{69}$ in these latter cases the Bankruptcy Act will be inapplicable and the buyer may avail himself of his remedy under section 2-502.

63. The Bankruptcy Act defines a preference as ". . . a transfer, as defined in this Act, of any of the property of a debtor to or for the benefit of a creditor for or on account of an antecedent debt, made or suffered by such debtor while insolvent and within four months before the filing by or against him of the petition initiating a proceeding under this Act, the effect of which transfer will be to enable such creditor to obtain a greater percentage of his debt than some other creditor of the same class." Id. at 25,11 U.S.C. $\$ 96 \mathrm{a}(1)$ (1952). Section $96 \mathrm{~b}$ provides for voiding such preferences under certain circumstances. 52 STAT. 870 (1938), 11 U.S.C. $\$ 96 \mathrm{~b}$ (1952).

64. UCC, Supplement No. 1, at 103 (Sub-Committee Report 1955).

65. In re Shipley Stave \& Lumber Co., 29 F. Supp. 746 (E.D. Ky. 1939). But cf. Quittner v. Los Angeles Steel Casting Co., 202 F.2d 814 (9th Cir. 1953).

66. Ely \& Walker Dry Goods Co. v. Adams Mfg. Co., 105 F.2d 906 (2d Cir. 1939); cf. Huseby v. Kilgore, 32 Wash. 2d 179, 201 P.2d 148 (1948).

67. Compare Quittner v. Los Angeles Steel Casting Co., 202 F.2d 814 (9th Cir. 1953), with Grief Bros. Cooperage Co. v. Mullinix, 264 Fed. 391 (8th Cir. 1920).

$6 \dot{8}$. This is one of the three definitions of "insolvent" UCC $\$ 1-201(23)$. Under the Bankruptcy Act, "a person shall be deemed insolvent within the provisions of this title whenever the aggregate of his property, exclusive of any property which he may have conveyed, transferred, concealed, removed, or permitted to be concealed or removed, with intent to defraud, hinder, or delay his creditors, shall not at a fair valuation be sufficient in amount to pay his debts;" 52 Stat. 841 (1946), 11 USC §1(19) (1952).

69. UCC \$1-201(23). 


\section{Buyer's Right to Specific Performance or Replevin: Section 2-716}

The second possessory remedy which the Code gives to the buyer is found in section 2-716 which provides:

"(3) The buyer has a right of replevin for goods identified to the contract if after reasonable effort he is unable to effect cover. . .."

This provision gives the remedy of replevin only to the buyer who cannot cover, i.e., make a reasonable purchase of goods in substitution for those due from the seller. ${ }^{70}$ In its application to the type of problem considered by this Note, it appears that where a buyer cannot cover, and thus has a right to possession, he may nonetheless fail to obtain the goods if a creditor can treat the sale as fraudulent under section 2-402. If the buyer can cover, he cannot assert a right to replevin, and there would be no need to apply the theory of fraudulent retention to prevent his recovery of the goods.

It is questionable, however, whether the requirement that buyer be unable to cover in order to be entitled to the specific remedy of section 2-716 was meant to apply in the event of the seller's insolvency. To be sure, the language of the section does not restrict its operation to cases of solvent sellers. Yet its refusal of a remedy to the buyer. who can cover is inequitable when seller is insolvent. The distinction places some buyers in the role of general creditors of an insolvent debtor with little chance of full recovery while others get the goods they want from the seller without loss. It appears, therefore, that cases will arise in which the application of section 2-402 would determine that as against the creditor, the buyer prevails because the retention by the seller was not fraudulent and yet the buyer is unable to find a Code provision which gives him a right to possession. This buyer is one whose goods have been identified to the contract, ${ }^{71}$ but who can cover. Of course, section $2-502$ partially fills the need of the buyer who can cover, but its scope is very narrow.

It is reasonable to suppose that the draftsmen did not intend thus to cut off the rights of a group of buyers. If it is assumed that the failure to provide a specific remedy for such a case was inadvertent, a court might resort to section 1-106(2) which provides:

"Any right or obligation declared by this Act is enforceable by action unless the provision declaring it specifies a different and limited effect."

The comment clarifies that an action should be allowed when a right exists "even though no remedy may be expressly provided." 72 To authorize a

70. UCC $\$ 2-712(1)$.

71. The identification of the goods to the contract establishes the applicability of $\$ 2-402$ and is a prerequisite to replevin under $\$ 2-716$.

72. UCC §1-106(2), comment 2. 
buyer to recover under a remedy fashioned from this section, the court must read section 2-402 as giving the buyer a right, and not merely creating a power in the creditors to cut off certain rights of the buyers. Such an interpretation avoids the inequities of the present statutory pattern, but it is manifestly more desirable that amendments be made to provide the buyer a broader remedy in the event of the seller's insolvency. It may be possible to achieve this result by a liberal construction of the provision which defines cover in terms of "reasonable purchase" elsewhere. ${ }^{73}$ If a court were to assume that such purchase is reasonable only if the buyer is able to recover adequate damages from the seller, the buyer may be entitled to replevin.

An alternate path to a broader remedy may be section 2-716(1) which provides:

"Specific performance may be decreed when the goods are unique or in other proper circumstances."

The comment to this section states it continues general prior policy as to specific performance and seeks to further a more liberal attitude than some courts have shown. ${ }^{74}$ Since under prior law, specific performance for the buyer when the seller was insolvent was not generally available though it was possible for the buyer to procure the goods under certain circumstances, ${ }^{75}$ it remains unclear whether the new liberal attitude referred to in the comment was intended to permit specific performance in the insolvency situation. Even if the court were inclined to permit specific performance under section 2-712(1) or to stretch the reasonable requirement in section 2-716(1), both of these constructions are open to the objection that they create voidable preferences under the federal bankruptcy act. ${ }^{76}$

\section{The Secured Transaction Article}

The Code's attempt to reconcile the competing claims of the buyer and seller's creditors cannot be analyzed without considering the impact of article 9 on secured transactions. It will be recalled that the primary justification for allowing the buyer to recover goods that were in the seller's possession at insolvency is to aid the buyer who has made an advance payment. If article 9 were applicable, it would afford the prepaying buyer an opportunity to protect his claim to the goods by filing a financing statement which would perfect the interest 77 and give notice to the creditors.

The utility of the solution offered by article 9 will depend on whether or not a buyer is entitled to a security interest, but this determination proves

73. UCC $\$ 2-712(1)$.

74. UCC $\$ 2-716(1)$, comment 1 .

75. See note 54 supra.

76. See discussion in text at notes 63-69 supra.

77. UCC \$9-302. 
difficult. The strongest evidence that a buyer may have such a security interest is found in the language of section 9-204(6) that:

"When a buyer makes an advance or otherwise gives new value for the purpose of enabling his seller to obtain or manufacture goods, a security interest in favor of the buyer attaches to the goods by virtue of the contract for sale as soon as they have become identified to the contract."

The purpose of this section is to provide when a security interest attaches, not to define what is a security interest. However, the unmistakably clear reference to a security interest in certain buyers who make advance payments is a strong indication that such an interest does exist. ${ }^{78}$

A countervailing implication can be drawn from the Code's definition of security interest in section 1-201(37) which states:

"'Security interest' means an interest in property which secures payment or performance of an obligation . . . The term also includes the interest of a financing buyer of accounts, chattel paper, or contract rights."

Since the specific reference to a financing buyer does not mention a buyer of goods, his security interest must fall within the general definition of the first sentence, if it is to fit under section 1-201(37) at all. That general definition seems to contemplate the typical case of a chattel security arrangement in which the creditor's right to receive money due on a debt is secured by the additional right to take possession of the goods in case of the debtor's default. In the case of a financing buyer, however, there is only one right, namely the right to receive the goods. That is not contingent upon default in the payment or performance of an obligation.

The conflict in the provisions of these two sections may be resolved by resort to the comments to section 9-204 which provide: "[T] his subsection provides .. . that the security interest attaches: for the security interest to prevail over creditors in cases of the seller's insolvency the buyer will have to perfect his interest by filing." 79

The apparent conclusion that the financing buyer has a security interest despite the incompatibility of section 1-201(37) gives rise to a further problem of the scope of transactions where the buyer can obtain this security interest. If the language of section 9-204(6) is accepted as the definition of the security interest, the financing buyer is included only where there are prepayments made for the purpose of enabling the seller to obtain or manufacture the goods. It is not clear whether it is the intent of the buyer alone or the intent of both parties that determines that the advance was for the requisite purpose. It is obvious, however, that a prepayment can

78. Further support for this proposition is found in comment 9 to $\$ 9-204$. See discussion at pp. 109-10 infra.

79. UCC $\$ 9-204(6)$, comment 9. 
be made for other purposes. For example, the purpose of the prepayment might be to assure the seller that the buyer will perform when the goods are completed. Such a payment, indicative only of the relative bargaining positions of the parties, is outside the transaction described in the statute. Other economic or commercial reasons that may underlie a prepayment would not entitle the buyer to a security interest in this narrow sense. ${ }^{80}$ Considered in terms of the overall problem of the conflict of interests between the buyer and the seller's creditors, the solution offered by article 9, if given the construction indicated by the language of section 9-204(6), protects but a fraction of the buyers who may become involved in this situation.

An alternate decision as to the scope of buyer's security interest would be to construe the general section, 1-201(37), to be broad enough to include all prepaying buyers. This can be done by ignoring the dual rights to which section 1-201(37) seems to refer in its first sentence ${ }^{81}$ so that any prepayment transaction is encompassed. If that is done, it is possible that all prepayment arrangements between the buyer and the seller may be deemed security interests, not only those in which the advance is made for the purpose of enabling the seller to obtain or manufacture the goods. Such an expansion of the scope of article 9 was probably unintended by the draftsmen of the Code, but none of the provisions of article 9 require a contrary result. Indeed, the draftsmen stated in the comments to the first section of the article that they intended to simplify the law and present an opportunity for the development of new forms of security arrangements without the need for new legislation. ${ }^{81 a}$ If the provisions of article 9 were intended to apply to the prepaying buyer, this should be clarified and the scope of the transaction covered should be explicitly delineated so that inferences arising from inconsistent interpretations of sections 9-204(6) and 1-201(37) are unnecessary.

\section{The Interplay of Article 2 and Article 9}

The preceding sections indicate that both article 2 and article 9 have attempted to resolve in some way the conflicting interests of the buyer and the seller's creditors when the seller becomes insolvent while still in possession of the goods. Unfortunately, it is not at all clear what the effect will be where the various provisions call for different results. Even if the inconsistencies within each article are settled, there is a further possibility that the decisions based on each article will conflict.

80. See, e.g., Perlman v. Feldmann, 219 F.2d 173 (2d Cir. 1955). The Korean war's demands on the steel industry caused a period of short supply which would ordinarily have operated to force steel prices up. Instead the industry maintained its old prices while taking advantage of the favorable marketing situation to raise prices indirectly by requiring purchasers to make interest-free advances of the purchase price long before delivery. Such a prepayment is clearly not an enabling advance, nor is it security guaranteeing performance by the buyer.

81. See discussion following note 72 supra.

81a. UCC \$9-101, comment. 
The first problem is to reconcile the security interest under article 9 with the remedy of section 2-502. Both apply only in the event that there has been some prepayment by the buyer and both take effect at the time the goods are identified to the contract. The narrow security interest defined from the wording of section 9-204(6) restricts the article 9 coverage to the buyer who pays in advance for the purpose of enabling the seller to obtain or manufacture the goods in question. Section 2-502 applies to any prepayment without regard to its purpose. The ten day restriction found in section 2-502, on the other hand, is inapplicable in considering the security interest of the buyer. Therefore, it is possible that cases can arise in which the buyer would prevail under both article 9 and section 2-502, or neither, but the real trouble stems from the cases in which the buyer succeeds under one but not the other of these protections. The comment to section 2-502 hints that if that section is applicable, there is no need to look further. It states:

"The question of whether the buyer also acquires a security interest in identified goods and has rights to the goods when insolvency takes place after the ten-day period provided in this section is governed by the provisions of the Article on Secured Transactions." 82

If that be the accepted interpretation, it means that any buyer who makes a prepayment, whether it be an enabling advance or a deposit to guarantee performance, is protected by section 2-502 for ten days. Even if such a buyer is eligible to have an article 9 security interest and has failed to comply with the filing requirements necessary to perfect his interest, ${ }^{83}$ he is nevertheless protected for ten days. After that period, only those buyers who have made enabling advances can obtain the security interest.

Under the above analysis of the interplay of section 2-502 and article 9 , serious difficulties are discovered in an attempt to find the place of section 2-402 in the pattern. It is not unreasonable to assume that section $2-402$ should be the keystone in the Code's handling of this problem since it is the only section which purports to deal with the conflict of the buyer and the seller's creditors.

In an earlier section, the interaction of sections 2-402 and 2-502 was considered. ${ }^{84}$ It is also necessary to determine whether or not a buyer who may be entitled to the security interest mentioned in section 9-204(6) must also qualify within the merchant-seller exception of section $2-402$.

There is some evidence in the Code itself that the two provisions are not interdependent. Comment 9 to section 9-204(6) states that under the common-law rule a seller's retention of the goods sold might be held fraud-

82. UCC \$2-502, comment 2. (Emphasis added.). The italicized portions of the quotation indicate that the right to get a security interest or the right to the goods after ten days are additional rights which are separate and distinct from the right granted by $\$ 2-502$.

83. See UCC \$9-302.

84. See discussion at text following notes 57 and 58 supra. 
ulent. The comment continues that this section is designed to reverse that common-law rule:

"This subsection gives such a buyer the wherewithal to subject the goods, which are being manufactured for him and for which he has made advances, to a security interest in his favor."

No mention is made of section 2-402, and no cross-reference to article 2 is indicated. If the security interest is sufficient to overrule the common law, there is no reason for looking to article 2 to decide the proper application of the security interest provision.

In their comments to section $2-402$, on the other hand, the draftsmen of the Code do refer to article 9 saying:

“. . . an enabling advance . . . is recognized as in current course of trade and is specifically protected in this Act (Article 9)." ${ }^{85}$

It seems probable that the "enabling advance" referred to is the same prepayment treated in section 9-204(6). However, the sentence appears in a comment which apparently aims to clarify "current course of trade" and "commercially reasonable time." These are tests for the application of section 2-402.

It may be argued that this comment is evidence of an intent to apply both the tests of section 2-402 and those connected with a security interest to a transaction which begins with an enabling advance. The analysis would be as follows: the buyer who makes an enabling advance is entitled to obtain a security interest to protect his investment under article 9; nevertheless, the draftsmen have stated that such an 'enabling advance qualifies under one of the tests of section 2-402; presumably, therefore, all the standards of section 2-402 are applicable to the enabling transaction and the buyer can lose his rights to the specific goods in which he has a perfected security interest when the creditors can void the sale as fraudulent under section $2-402, e . g$., the buyer is not dealing with a merchantseller. Such a conclusion is not prohibited by the language of the Code, but it sets a trap for the unwary buyer who relies solely on the protection of the security interest.

However, the conclusion rests on a basic premise which may not be valid, namely, that the security interest provision and the standards of section 2-402 are both applicable to a single transaction. An equally tenable inference, perhaps, is that the purpose of the comment was to cover cases in which the buyer, although entitled to a security interest for his enabling advance, did not perfect it. In such an event, he may still prevail unless the creditors can upset the sale as fraudulent. Thus the comment is saying that if article 9 is not conclusive, then section 2-402 applies.

85. UCC $\$ 2-402$, comment 2 . 
Any theory of the respective roles of article 2 and article 9 which rests on nothing more than the inference to be drawn from possible accidental language in an explanatory comment is manifestly not compelling. It is entirely possible, for example, that section $2-402$ is meant to apply only to those cases in which there has been no advance payment, or to those cases in which the buyer is not entitled to a security interest under article 9. Whatever be the conclusion that is worked out by the courts that must construe the Code, it is clear that the answer is not demanded by any clause presently found in the Act. 